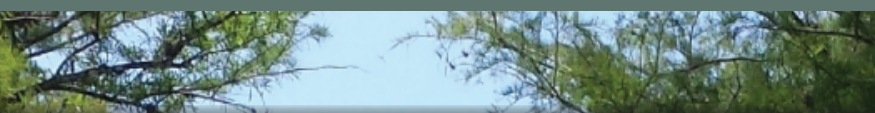

Greater Everglades Priority Ecosystem Science Program

\title{
Development and Application of Surrogate Models, Calculated Loads, and Aquatic Export of Carbon Based on Specific Conductance, Big Cypress National Preserve, South Florida, 2015-17
}

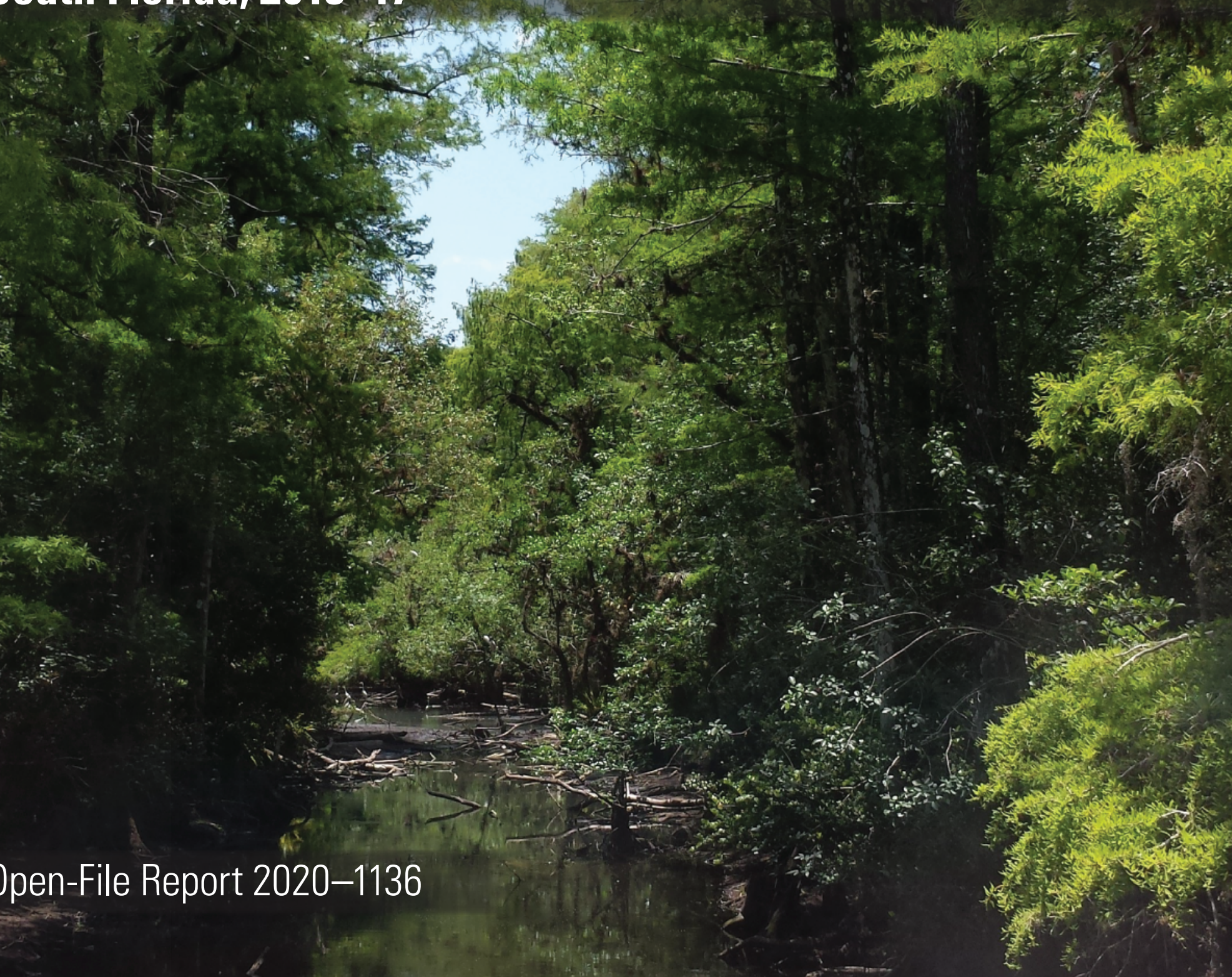

U.S. Department of the Interior U.S. Geological Survey 
Cover. Sweetwater Strand looking southwest from Loop Road, Big Cypress National Preserve, Florida. Photograph by Travis Knight, U.S. Geological Survey. 


\section{Development and Application of Surrogate Models, Calculated Loads, and Aquatic Export of Carbon Based on Specific Conductance, Big Cypress National Preserve, South Florida, 2015-17}

By Amanda C. Booth

Greater Everglades Priority Ecosystem Science Program

Open-File Report 2020-1136 


\title{
U.S. Department of the Interior \\ DAVID BERNHARDT, Secretary
}

\author{
U.S. Geological Survey \\ James F. Reilly II, Director
}

U.S. Geological Survey, Reston, Virginia: 2021

For more information on the USGS - the Federal source for science about the Earth, its natural and living resources, natural hazards, and the environment—visit https://www.usgs.gov or call 1-888-ASK-USGS.

For an overview of USGS information products, including maps, imagery, and publications, visit https://store.usgs.gov/.

Any use of trade, firm, or product names is for descriptive purposes only and does not imply endorsement by the U.S. Government.

Although this information product, for the most part, is in the public domain, it also may contain copyrighted materials as noted in the text. Permission to reproduce copyrighted items must be secured from the copyright owner.

Suggested citation:

Booth, A.C., 2021, Development and application of surrogate models, calculated loads, and aquatic export of carbon based on specific conductance, Big Cypress National Preserve, South Florida, 2015-17: U.S. Geological Survey Open-File Report 2020-1136, 14 p., https://doi.org/10.3133/ofr20201136.

Associated data for this publication:

Booth, A.C., 2021, Calculated carbon concentrations, loads, and export in Big Cypress National Preserve, South Florida, 2015-2017: U.S. Geological Survey data release, https://doi.org/10.5066/P9EXZLJT.

ISSN 2331-1258 (online) 


\section{Contents}

Abstract

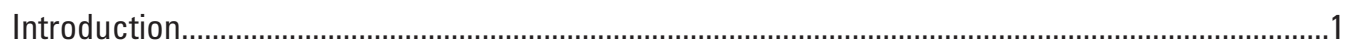

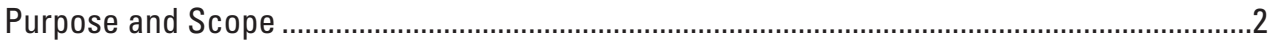

Description of Study Area ...............................................................................................

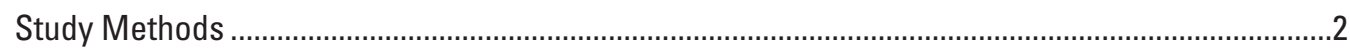

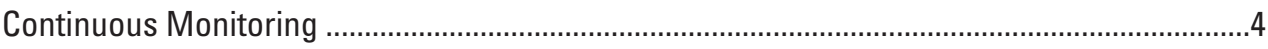

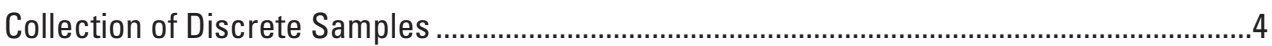

Development of Empirical Models ..........................................................................................

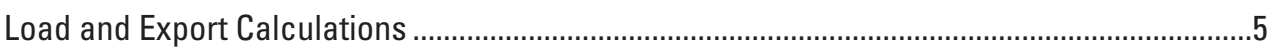

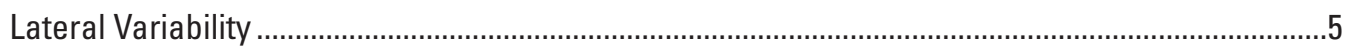

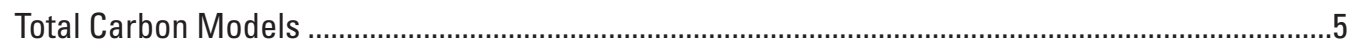

Total Carbon Concentrations, Loads, and Export ………...............................................................

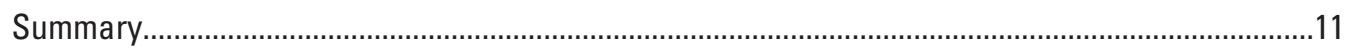

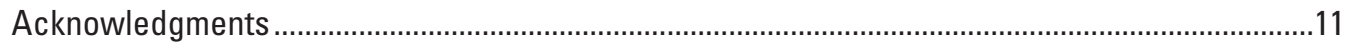

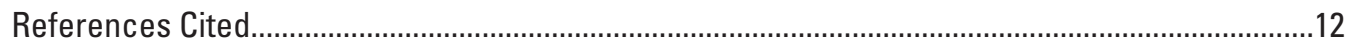

Appendixes 1-2.....................................................................https://doi.org/10.3133/ofr20201136

\section{Figures}

1. Map showing study area boundaries, monitor locations, bridges along Tamiami Trail, and culverts along Loop Road within Big Cypress National Preserve,

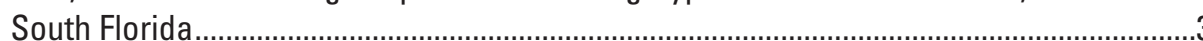

2. Graphs showing comparisons of specific conductance values during water-quality surveys and corresponding site monitor data ...............................................

3. Graphs showing observed concentrations of dissolved organic carbon, dissolved inorganic carbon, and particulate carbon at U.S. Geological Survey stations 02288900 and 02290947

4. Hydrographs showing calculated and observed total carbon concentrations and flow at U.S. Geological Survey stations 022889001 and 022909471

5. Graph showing daily total carbon loads at U.S. Geological Survey stations 022889001 and 022909471

6. Graph showing monthly total carbon loads at U.S. Geological Survey stations

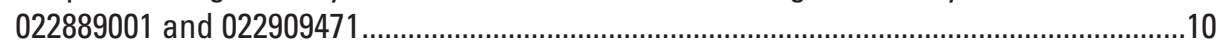

7. Graph showing monthly aquatic export of total carbon for the study area.....................11 


\section{Conversion Factors}

International System of Units to U.S. customary units

\begin{tabular}{|c|c|c|}
\hline Multiply & By & To obtain \\
\hline \multicolumn{3}{|c|}{ Length } \\
\hline centimeter (m) & 0.3937 & inch (in.) \\
\hline meter (m) & 3.281 & foot $(\mathrm{ft})$ \\
\hline meter (m) & 1.094 & yard (yd) \\
\hline kilometer (km) & 0.6214 & mile (mi) \\
\hline \multicolumn{3}{|c|}{ Area } \\
\hline square meter $\left(\mathrm{m}^{2}\right)$ & 0.0002471 & acre \\
\hline square meter $\left(\mathrm{m}^{2}\right)$ & 10.76 & square foot $\left(\mathrm{ft}^{2}\right)$ \\
\hline \multicolumn{3}{|c|}{ Volume } \\
\hline liter $(\mathrm{L})$ & 33.81402 & ounce, fluid (fl. oz) \\
\hline liter (L) & 2.113 & pint $(p t)$ \\
\hline liter $(\mathrm{L})$ & 0.2642 & gallon (gal) \\
\hline \multicolumn{3}{|c|}{ Mass } \\
\hline gram (g) & 0.03527 & ounce, avoirdupois (oz) \\
\hline metric ton $(\mathrm{t})$ & 1.102 & ton, short [2,000 lb] \\
\hline metric ton $(\mathrm{t})$ & 0.9842 & ton, long [2,240 lb] \\
\hline
\end{tabular}

Temperature in degrees Celsius $\left({ }^{\circ} \mathrm{C}\right)$ may be converted to degrees Fahrenheit $\left({ }^{\circ} \mathrm{F}\right)$ as follows: ${ }^{\circ} \mathrm{F}=\left(1.8 \times{ }^{\circ} \mathrm{C}\right)+32$.

Temperature in degrees Fahrenheit $\left({ }^{\circ} \mathrm{F}\right)$ may be converted to degrees Celsius $\left({ }^{\circ} \mathrm{C}\right)$ as follows: ${ }^{\circ} \mathrm{C}=\left({ }^{\circ} \mathrm{F}-32\right) / 1.8$.

\section{Datum}

Horizontal coordinate information is referenced to the North American Datum of 1983 (NAD 83).

\section{Supplemental Information}

Specific conductance is given in microsiemens per centimeter at 25 degrees Celsius $(\mu \mathrm{S} / \mathrm{cm}$ at $\left.25^{\circ} \mathrm{C}\right)$.

Concentrations of chemical constituents in water are given in milligrams per liter (mg/L). 


\section{Abbreviations}

$\begin{array}{ll}\text { DIC } & \text { dissolved inorganic carbon } \\ \text { DOC } & \text { dissolved organic carbon } \\ \text { fDOM } & \text { fluorescence of dissolved organic matter } \\ \text { NWIS } & \text { National Water Information System } \\ \text { NWOL } & \text { National Water Quality Laboratory } \\ \text { RMSE } & \text { root mean square error } \\ \text { SC } & \text { specific conductance } \\ \text { TC } & \text { total carbon } \\ \text { TPC } & \text { total particulate carbon } \\ \text { USGS } & \text { U.S. Geological Survey }\end{array}$





\title{
Development and Application of Surrogate Models, Calculated Loads, and Aquatic Export of Carbon Based on Specific Conductance, Big Cypress National Preserve, South Florida, 2015-17
}

\author{
By Amanda C. Booth
}

\section{Abstract}

Understanding the carbon transport within aquatic environments is crucial to quantifying global and local carbon budgets, yet limited empirical data currently (2021) exist. This report documents methodology and provides data for quantifying the aquatic export of carbon from a cypress swamp within Big Cypress National Preserve and is part of a larger carbon budget study. The U.S. Geological Survey operated two continuous monitoring stations, 022889001 and 022909471, that measured flow volume and water quality within the Big Cypress National Preserve in South Florida from September 2015 to October 2017. Station 022889001 represented the flow into the study area and station 022909471 represented the flow out of the study area. Site-specific regression models were developed by using continuously measured specific conductance and concomitant, discretely collected dissolved organic carbon, dissolved inorganic carbon, and particulate carbon samples to calculate total carbon (TC) concentrations at 15-minute intervals.

Calculated TC concentrations typically increased as flow was decreasing and decreased as flow was increasing. TC loads were calculated by multiplying concentrations and flow volume, and the difference between the load calculations for input/output locations of the swamp flow system was used to determine the aquatic carbon export from the study area.

Calculated monthly TC loads ranged from 0 metric tons in spring 2017 at both stations to 3,145 and 7,821 metric tons in September 2017 at 022889001 and 022909471 , respectively. During 2016, the annual loads were 10,479 and 15,243 metric tons at 022889001 and 022909471 , respectively. Calculated monthly aquatic TC exports from the study area ranged from -0.7 gram of carbon per square meter in May 2016 to 44.1 grams of carbon per square meter during September 2017. The carbon export from the study area varied monthly, increased as flow increased, and was greatly influenced by Hurricane Irma in September 2017. The aquatic TC export from the Sweetwater Strand study area was 42.0 grams of carbon per square meter per year in 2016, which is substantially (about 15 times) larger than the estimated overall mean riverine carbon export per square meter for the eastern United States; however, it was also less than the monthly export of carbon in September 2017. The monthly aquatic carbon export from the study area in September 2017 alone was greater than the aquatic carbon export from all of 2016, which is largely the result of the substantial increase in flow attributed to Hurricane Irma.

\section{Introduction}

Carbon gases play a role in the Earth's climate, including temperature and weather events, and the carbon cycle encompasses the flow, storage, and transformation of carbon compounds that are vital for life, including food and energy production (Bruhwiler and others, 2018). The lateral carbon export from the landscape to surface water is an important component of the global carbon cycle. The Energy Independence and Security Act of 2007 required an assessment of carbon including exports from freshwater aquatic ecosystems. While the amount of empirical data is limited, the U.S. Geological Survey (USGS) provided estimates for several geographic areas. Riverine ecosystems were estimated to export dissolved inorganic and total organic carbon at a rate of 6.4 grams carbon per square meter per year $\left(\mathrm{gC} / \mathrm{m}^{2} / \mathrm{yr}\right)$ in the eastern United States (Stackpoole and others, 2014), $3.4 \mathrm{gC} / \mathrm{m}^{2} / \mathrm{yr}$ in the western United States (Stackpoole and others, 2012), and $12.2 \mathrm{gC} / \mathrm{m}^{2} / \mathrm{yr}$ in Alaska (Stackpoole and others, 2016).

In addition to global carbon cycle contributions, the flow component of carbon export of the greater Everglades is a critical piece of information for Everglades restoration adaptive management efforts. For millennia, coastal wetlands such as the Florida Everglades have either accumulated or lost organic peat soil, depending upon urban or natural hydrologic conditions, controlled and uncontrolled fires, and the balance between ecosystem photosynthesis and respiration (Dreschel and others, 2017). Understanding all components of 
the carbon cycle is critical information for managers because as flow restoration progresses, coastal communities face sealevel rise, and changes in precipitation patterns and hurricane impacts affect the carbon flow component. Previous studies have estimated aquatic carbon (dissolved inorganic and total organic) export in marsh and mangrove systems in the Everglades by combining estimates for net ecosystem exchange (by gas exchange between landscape and atmosphere) and net ecosystem carbon balance; the marsh export was estimated as $666 \pm 61 \mathrm{gC} / \mathrm{m}^{2} / \mathrm{yr}$ for Shark River Slough and $407 \pm 63 \mathrm{gC} / \mathrm{m}^{2} / \mathrm{yr}$ in Taylor Slough, while mangrove carbon export was about $-131 \pm 155 \mathrm{gC} / \mathrm{m}^{2} / \mathrm{yr}$ (Troxler and others, 2013).

This study, conducted as part of the Greater Everglades Priority Ecosystems Science Program, developed two sitespecific surrogate models for calculating concentrations of total carbon (TC), which includes dissolved organic carbon (DOC), dissolved inorganic carbon (DIC), and total particulate carbon (TPC) in a cypress swamp within Big Cypress National Preserve. Loads were calculated by using the calculated concentration data and concurrent flow data. This report provides the first empirical assessment of carbon exports within a cypress swamp in South Florida by using continuous in situ measurements (15-minute intervals). Continuous data on aquatic carbon export can be used to describe seasonal and annual variability of constituent concentrations, inform the understanding of carbon cycling and transport mechanisms within the greater Everglades landscape, and potentially provide insights into the effects of restoration efforts on carbon cycling.

\section{Purpose and Scope}

The purpose of this report is to document site-specific regression models to calculate concentrations of TC from September 2015 to October 2017 within a defined boundary of Big Cypress National Preserve (fig. 1). Two models were developed to calculate 15-minute TC concentrations and loads representing the input and the output for the defined area. All continuous and discrete data are available for download at the National Water Information System (NWIS) database (U.S. Geological Survey, 2019). Models are documented within this report and additional details are available in the appendixes. The difference between the upstream and downstream load calculations divided by the study area is being used to determine the aquatic carbon export derived from the study area; these export estimates will be used as input for a larger carbon budget study.

\section{Description of Study Area}

The study area is approximately 106 square kilometers and is bounded by Tamiami Trail (U.S. 41) and Loop Road within Big Cypress National Preserve in South Florida (fig. 1). The USGS site Tamiami Canal outlets, 40-Mile Bend to Monroe, Florida (02288900) represents the entire flow from bridges 96 to 117 and 22 to 28 along Tamiami Trail. The USGS site Tamiami Canal 11 Mile Road to Monroe
Station, Fla. (022889001) represents the flow from bridges 97 to 108 along U.S. 41 between 11 Mile Road and Monroe Station (and, therefore, a part of what is included in the flow component of station 02288900). The USGS site Sweetwater Strand at Loop Road, near Monroe Station, Fla. (02290947) represents the four culverts at the Sweetwater Strand bridge. The USGS site Loop Road culverts Monroe Station to Florida Trail, Fla. (022909471) represents the flow at all culverts from bridges numbered 0 to 31 (a total of 40 culverts), including the four culverts at the Sweetwater Strand bridge.

Station 022889001 represents the input into Sweetwater Strand from Tamiami Trail, and station 022909471 represents outflow along Loop Road. The model boundaries were estimated by plotting water-level gradient vectors in R statistical software using the rasterVis package (Perpinan, 2016). The water level of each 400 -meter by 400 -meter cell used by the Everglades Depth Estimation Network (EDEN) model relative to that of each of its eight neighbors was analyzed to determine the magnitude and direction of water-level surface slope in the area within the following four points referenced using North American Datum of 1983: lat 25 51' $36^{\prime \prime}$ N., long $81^{\circ} 5^{\prime} 60^{\prime \prime} \mathrm{W}$.; lat $25^{\circ} 50^{\prime} 24^{\prime \prime} \mathrm{N}$., long $80^{\circ} 55^{\prime} 12^{\prime \prime} \mathrm{W}$.; lat $25^{\circ} 45^{\prime} 36^{\prime \prime} \mathrm{N}$., long $81^{\circ} 0^{\prime} 0^{\prime \prime} \mathrm{W}$.; and, lat $25^{\circ} 45^{\prime} 36^{\prime \prime} \mathrm{N}$., long $81^{\circ} 5^{\prime} 60^{\prime \prime} \mathrm{W}$. The direction of the water level surface slope was used to estimate flow direction and extrapolate the study area boundary. Data input files are available from archives (EDEN and U.S. Geological Survey, 2016).

The study area is predominately cypress swamp, with tall, dense cypress trees and a subcanopy of mixed hardwoods. The substrate is primarily limestone bedrock with organic accumulations in rock depressions. Average annual rainfall for South Florida is 135 centimeters (Abtew and Ciuca, 2017), and rainfall predominately occurs during June to October. Hurricane Irma made landfall in Florida approximately 72 kilometers west of the study area as a category 3 storm on September 10, 2017, and yielded rainfall amounts of 25-38 centimeters along the peninsula (Cangialosi and others, 2017).

\section{Study Methods}

Various methods and procedures were followed to collect and analyze the data used to develop the empirical models to simulate concentrations and calculate loads of TC. Continuous (15-minute interval) data collected included water level, flow volume, and water quality. Water-quality data collected included specific conductance (SC), temperature, turbidity, and fluorescence of dissolved organic matter (fDOM). Data were transmitted on an hourly basis via the Geostationary Operational Environmental Satellite and made available to the public on a near real-time basis. Discrete water samples were collected monthly from September 2015 to October 2017. Data collected for this report are available from the USGS NWIS database (U.S. Geological Survey, 2019). Development of the models was guided by procedures described in Rasmussen and others (2009). 


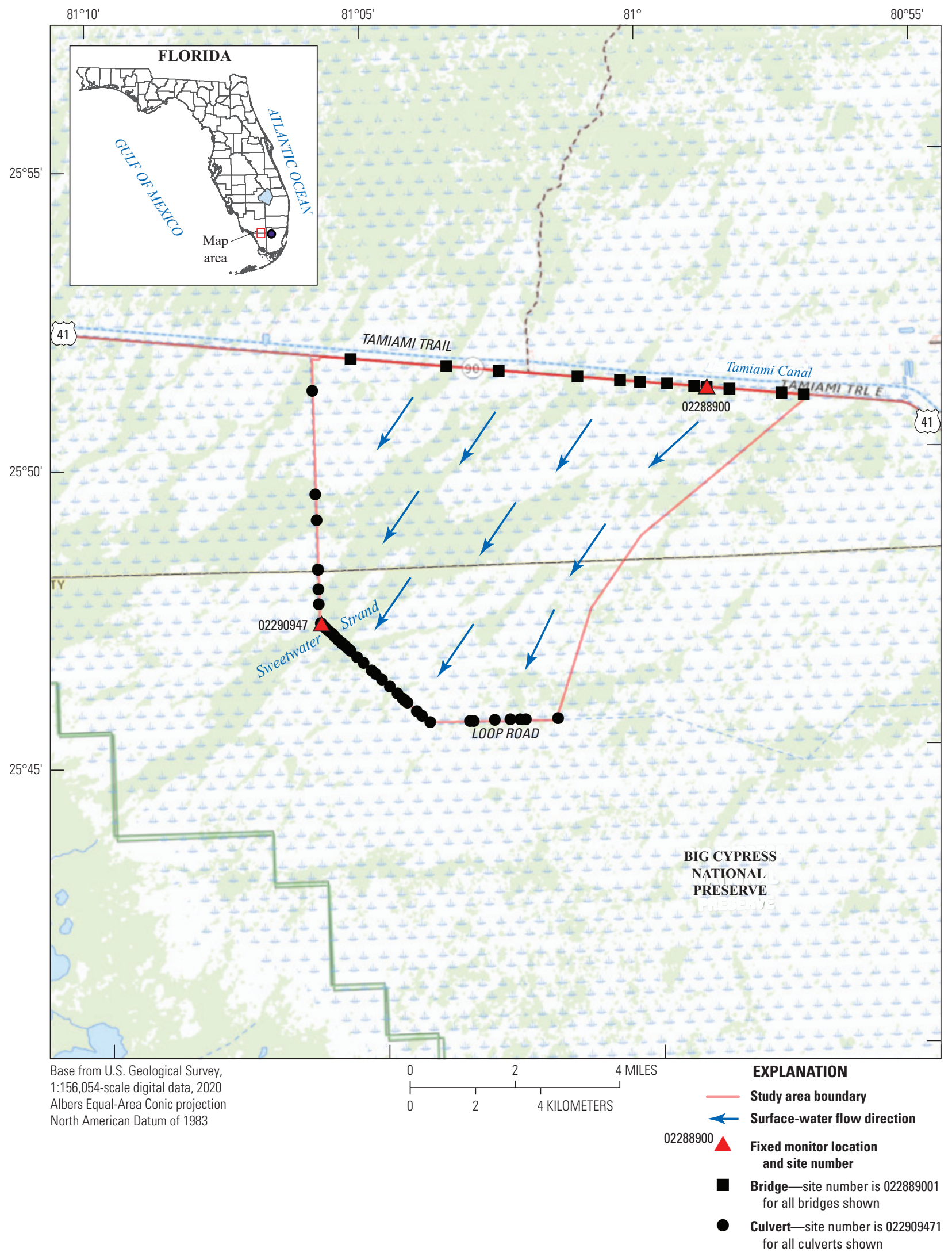

Figure 1. Study area boundaries, monitor locations, bridges along Tamiami Trail, and culverts along Loop Road within Big Cypress National Preserve, South Florida. 
Surrogate Models, Calculated Loads, Aquatic Export of Carbon Based on Specific Conductance

\section{Continuous Monitoring}

Water-level measurements were collected following procedures in Sauer and Turnipseed (2010) by using shaft encoders with a pulley and float system upstream at 02288900 and a pressure transducer at 02290947 . Flow was calculated by using a stage-discharge relationship, with stage measured at gaging stations 02288900 and 02290947 (Rantz, 1982). Flow measurements were made with a Sontek Flowtracker acoustic Doppler velocimeter with the internal settings set to general mode. The acoustic Doppler velocimeter was attached to a top-setting wading rod and deployed in each culvert opening at each bridge from the downstream bridge wall for a duration of 40 seconds. The dimensions of each culvert were measured to develop area ratings for flow computations. A macro within Microsoft Excel was developed to calculate the flow for each bridge by using water velocity and elevation data and known culvert dimensions, which then summed the flow for the bridges to calculate the flow for the entire reach.

A YSI EXO2 sensor collected water-quality data in situ from September 2015 to October 2017 at 02290947 and 02288900. Data recorded included SC, in microsiemens per centimeter at 25 degrees Celsius $\left(\mu \mathrm{S} / \mathrm{cm}\right.$ at $\left.25^{\circ} \mathrm{C}\right)$; water temperature, in degrees Celsius; turbidity, in formazin nephelometric units; and fDOM, in quinine sulfate equivalents - the concentration of quinine sulfate dehydrate in parts per billion that results in an equivalent instrument response. The YSI EXO2 sensors were inspected for fouling approximately every 4 weeks, and calibration verifications were performed every 8 weeks. Drift and fouling corrections were determined and applied by using procedures and formulas provided in Wagner and others (2006).

To ensure that the data recorded at the fixed monitoring locations at stations 02290947 and 02288900 were representative of the entire flow represented by 022909471 and 022889001, water-quality sensors were placed at middepth at the center of the bridge at each site (12 locations along Tamiami Trail, bridges 97-108, and 40 locations along Loop Road). These water-quality surveys were completed to estimate lateral variability during multiple dates that spanned the range of hydrologic conditions observed during the study period. Parameters recorded for surveys were the same as for the in situ sensor. To ensure data comparability between cross-sectional profiles and in situ readings, the same qualityassurance procedures as for in situ sensors were used.

\section{Collection of Discrete Samples}

Point grab samples were collected at the location and depth of water-quality sensors at 02288900 and 02290947 by using procedures outlined in the USGS National Field Manual (U.S. Geological Survey, variously dated). Samples were analyzed for DOC, DIC, and TPC by the USGS National Water Quality Laboratory (NWQL) in Denver, Colorado. Replicates and blanks were collected over a range of flows throughout the study period and are summarized in appendixes 1 and 2 .
DOC samples were filtered through a 0.45 -micrometer $(\mu \mathrm{m})$ capsule filter into amber glass 125-milliliter bottles within 15 minutes of being collected, stored immediately on ice, and shipped within 24 hours of collection. DOC samples were analyzed by high-temperature catalytic combustion following procedures in Clescrei and others (1998). DIC samples were filtered through a $0.45-\mu \mathrm{m}$ capsule filter into amber glass 125-milliliter bottles within 15 minutes of collection, placed on ice, and shipped within 24 hours of collection. DIC samples were analyzed by high-temperature catalytic combustion at the NWQL and are summarized in appendixes 1 and 2. At the time of data collection, DIC was not an approved method at the laboratory; therefore, data are not available in NWIS.

TPC samples were filtered through a $0.7-\mu \mathrm{m}$ glass fiber filter by using a fluorocarbon polymer pressure-filtration assembly, folded in half, placed in a foil pouch that was then placed in a polyethylene Whirl-Pak bag, placed on ice, and shipped within 24 hours of collection. Samples were analyzed by high-temperature combustion at the NWQL by using U.S. Environmental Protection Agency (EPA) Method 440 (Zimmerman and others, 1997).

\section{Development of Empirical Models}

Two site-specific surrogate models were developed for calculating TC concentrations at the two study sites. Regression analysis was done by using Microsoft Excel and the USGS Surrogate Analysis and Index Developer tool (Domanski and others, 2015) to compare relations with continuously measured data and concomitant carbon species concentrations. The distribution of residuals was examined for normality, and plots of residuals (the difference between the observed and calculated values) were examined for homoscedasticity (equal variance). In short, models were selected on the basis of residual plots, relatively high coefficient of determination $\left(\mathrm{R}^{2}\right)$ values, and root mean square error (RMSE) values. Model archive summaries for each constituent are available in the appendixes.

To develop empirical models for estimating continuous records of carbon concentrations that are comparable across sites and over time, instrument characteristics and site-specific environmental conditions need to be considered and multiple linear regressions employed (Rasmussen and others, 2009). Temperature, turbidity, SC, and the fraction of chromophoric dissolved organic matter that fluoresces (fDOM) were all investigated as potential explanatory variables; fDOM is often used as a surrogate for DOC concentration (Spencer and others, 2007; Pellerin and others, 2012; Bergamaschi and others, 2012a, b). Ultimately, SC provided the best model output. The use of SC as a surrogate for DOC is also supported in other studies (Curtis and Adams, 1995; Monteiro and others, 2014). Turbidity data are often used as a proxy for particulate concentration (Rasmussen and others, 2009). Water temperature was also explored as a variable to account for seasonal variability. The accuracy of the models 
is highly dependent on the range of variables used in model development and whether predictive variables are linear when recorded values exceed those used in model development.

Carbon concentrations were calculated at 15-minute intervals for USGS stations 022889001 and 022909471 ; data are available through a USGS data release (Booth, 2021).

\section{Load and Export Calculations}

Loads were calculated by multiplying 15 -minute calculated carbon values by flow, converting the values to grams of carbon per 15 minutes, summing the 15 -minute data to calculate daily values, and converting the daily values to metric tons. Estimates for daily values were estimated using linear interpolation for September 22, 2015, and June 22-24, 2017, for station 022909471. The difference between the daily calculated loads at the two locations, 022889001 (representing input) minus 022909471 (representing output), divided by the total study area $(106,000,000$ square meters) was used to determine the total aquatic carbon export from the study area. Computed TC concentrations in milligrams per liter at 15-minute intervals, loads of carbon in grams per 15-minute interval, and daily values in metric tons are available for stations 02289901 and 022909471 in Booth (2021). When flow values were available and SC was missing for a period of less than 1 hour, the most recent SC value was used to calculate the concentration. Daily values for aquatic TC export from the study are in grams of carbon per square meter per day and are also available in Booth (2021).

\section{Lateral Variability}

A total of 17 water-quality surveys were completed between October 13, 2015, and August 9, 2017, for bridges 97-108 along Tamiami Trail (fig. 2A). The relative percent difference for the mean channel cross-section averages compared to the site monitor readings ranged from -8 percent to 7 percent, with a mean of -1 percent and a median of -2 percent. For reference, the calibration criteria of SC sensors in this study was 3 percent as outlined in Wagner and others (2006). The assumption was made that the water-quality data collected at USGS site 02288900 were representative of the 12 bridges represented by 022889001 under most conditions; therefore, no corrections were applied in order to calculate loads (fig. $2 A$ ).

A total of 20 water-quality surveys were completed between September 9, 2015, and August 10, 2017, for 022909471 (fig. 2B). The relative percent difference between mean channel cross-section averages and the site monitor ranged from -29 percent to 20 percent, with a mean and median of -5 percent. The assumption was made that the water-quality data at USGS site number 02290947 were representative of the 20 bridges represented by 022909471 under most conditions; therefore, no corrections were applied in order to calculate loads.

\section{Total Carbon Models}

SC was the explanatory variable for TC at both study sites and was positively related to TC.

The model form for TC at 022889001 is

$$
T C=(0.129 \times S C)+6.62,
$$

where

$$
\begin{aligned}
& T C \quad \text { is total carbon concentration, in milligrams } \\
& \text { per liter; and } \\
& S C \quad \text { is specific conductance, in microsiemens per } \\
& \text { centimeter at } 25 \text { degrees Celsius. }
\end{aligned}
$$

The regression model for 022889001 was based on 22 concurrent measurements of TC (DOC, DIC, and TPC) and SC samples collected from September 19, 2015, to October 3, 2017 (appendix 1). SC was the best predictor of TC concentration based on residual plots, with a relatively high $\mathrm{R}^{2}$ (0.96) and a relatively low RMSE (3.19) (appendix 1). Model development and diagnostic plots and tests are in the model archive summary (appendix 1).

The model form for TC at 022909471 is

$$
T C=(0.117 \times S C)+12 .
$$

The regression model for 022909471 was based on 21 concurrent measurements of TC (DOC, DIC, and TPC) and SC samples collected from June 16, 2015, to October 5, 2017 (appendix 2). SC at 022909471was the best predictor of TC concentration based on residual plots, with a relatively high $\mathrm{R}^{2}$ (0.82) and a relatively low RMSE (4.48). Model development and diagnostic plots and tests are in the model archive summary (appendix 2).

\section{Total Carbon Concentrations, Loads, and Export}

TC concentrations are composed of DIC, DOC, and TPC. Observed TC concentrations at 02288900 ranged from 31.2 milligrams per liter (mg/L) on July 11, 2016, to $81 \mathrm{mg} / \mathrm{L}$ on March 27, 2017 (fig. 3A). Discrete DIC at this site ranged from 20.9 to $69.7 \mathrm{mg} / \mathrm{L}$ and accounted for an average of 73 percent of the TC concentration. Observed DOC at the site ranged from 7.8 to $17.8 \mathrm{mg} / \mathrm{L}$ and accounted for an average of 24 percent of TC, and TPC ranged from 0.3 to $8.6 \mathrm{mg} / \mathrm{L}$ and accounted for an average of 2 percent of the TC concentration. TPC was primarily composed of particulate organic carbon. Inorganic particulate carbon was only detected in two samples and contributed a maximum of 0.2 percent of the TPC and less than 0.02 percent of the TC.

Observed TC concentrations at 02290947 ranged from $35 \mathrm{mg} / \mathrm{L}$ on September 20, 2016, to $70.7 \mathrm{mg} / \mathrm{L}$ on December 19, 2016 (fig. 3B). Observed DIC at this site ranged 

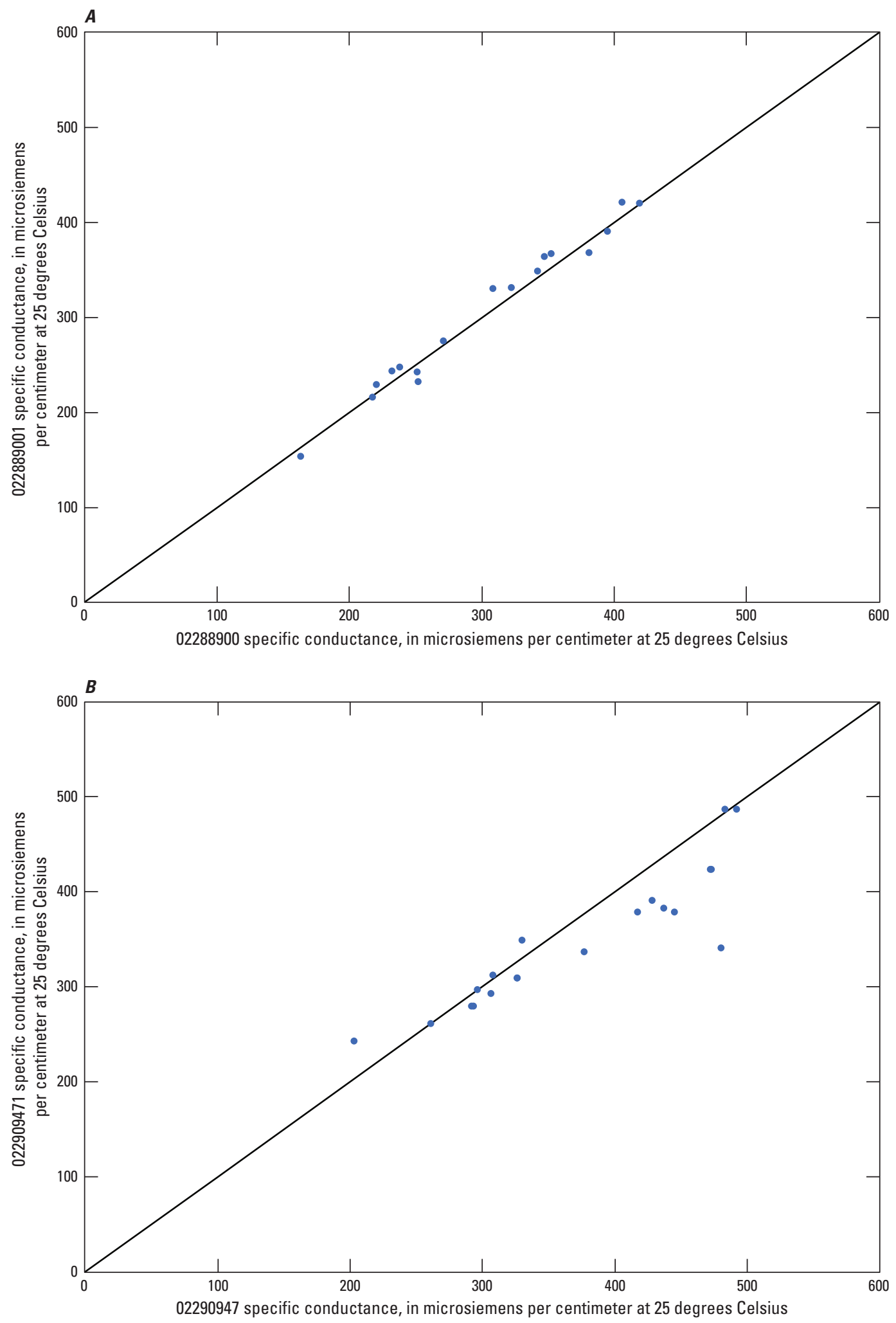

Figure 2. Comparisons of specific conductance values during water-quality surveys and corresponding site monitor data. A, Water-quality survey data representative of U.S. Geological Survey (USGS) station 022889001 and fixed monitoring point 02288900 . $B$, Water-quality survey data representative of USGS station 022909471 and fixed monitoring point 02290947 . The 1-to-1 lines are shown in black. 

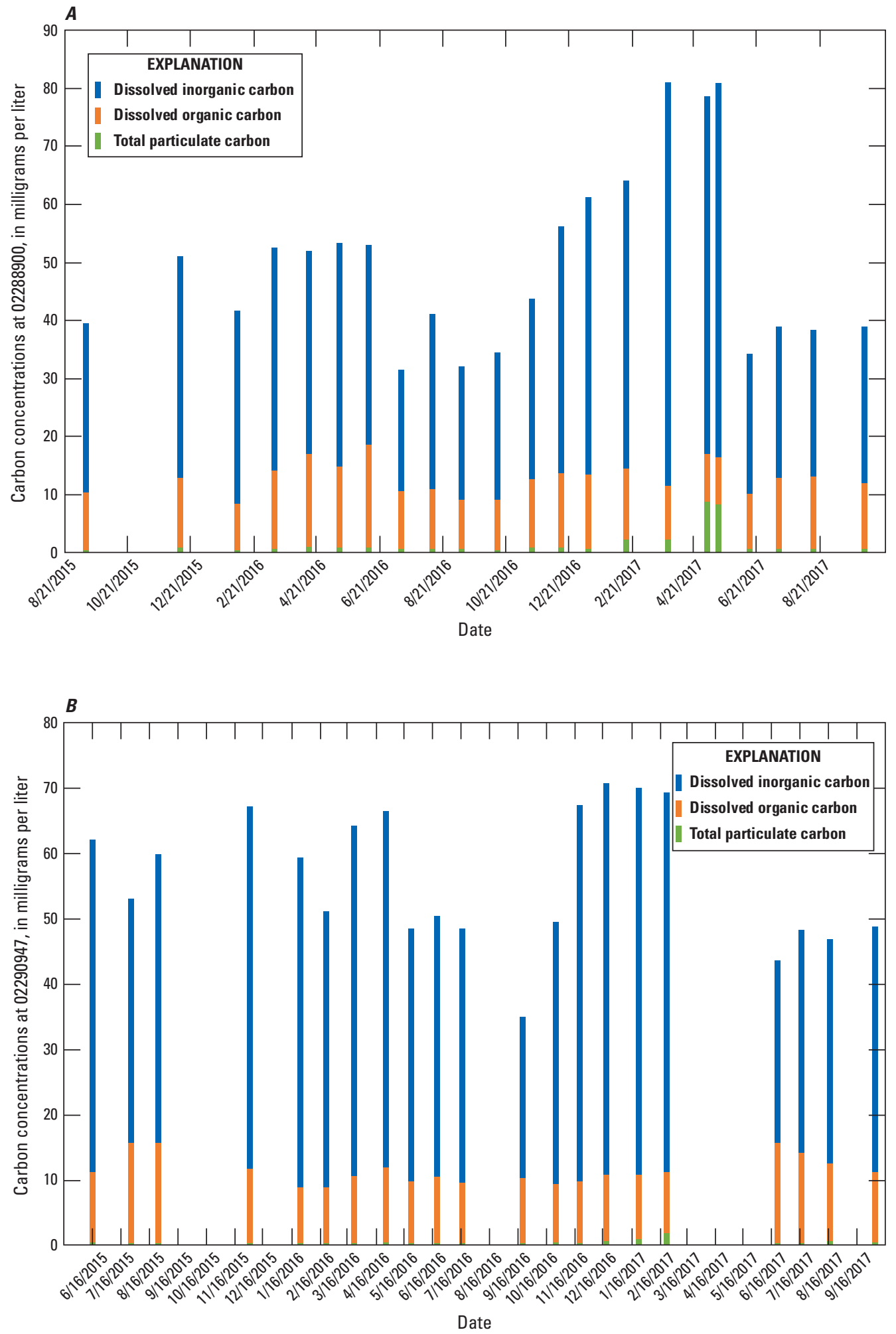

Figure 3. Observed concentrations of dissolved organic carbon, dissolved inorganic carbon, and particulate carbon at $A$, U.S. Geological Survey (USGS) station 02288900, and $B$, USGS station 02290947. 
from 24.8 to $59.9 \mathrm{mg} / \mathrm{L}$ and accounted for an average of 79 percent of the TC. Observed DOC at the site ranged from 8.6 to $15.4 \mathrm{mg} / \mathrm{L}$ and accounted for an average of 20 percent of the TC. TPC ranged from 0.1 to $1.8 \mathrm{mg} / \mathrm{L}$ and accounted for an average of 1 percent of the TC concentration.

The results for sites 02288900 and 02290947 indicate both the inorganic and organic carbon components are more important to quantify for future studies. Particulate carbon, however, composed as much as 11 percent of the TC at 02288900 in May 2017.

Calculated TC concentrations for 022889001 ranged from $18.3 \mathrm{mg} / \mathrm{L}$ on June 7, 2017, to $87.1 \mathrm{mg} / \mathrm{L}$ on May 13-14, 2017 (fig. 4A); the mean calculated TC was $49.2 \mathrm{mg} / \mathrm{L}$ for the study period. Calculated carbon concentrations for 022909471 ranged from $20.1 \mathrm{mg} / \mathrm{L}$ on June 6,2017 , to $74.6 \mathrm{mg} / \mathrm{L}$ on February 18, 2017 (fig. 4B); the mean calculated TC was $56.3 \mathrm{mg} / \mathrm{L}$ for the study period. Calculated TC concentrations at both locations typically increased as flow was decreasing and decreased as flow was increasing, likely caused by rainwater input.

Daily TC loads ranged from 0 metric tons ( $\mathrm{t}$ ) on multiple dates to $146 \mathrm{t}$ on September 12, 2017, at 022889001 (fig. 5). Daily TC loads ranged from 0 to $474 \mathrm{t}$ on September 12, 2017, at 022909471 (fig. 5). Monthly TC loads ranged from $0 \mathrm{t}$ in March, April, and May 2017 at 022889001 and $0 t$ in April and May at 022909471 to 3,145 and 7,821 $\mathrm{t}$ in September 2017 at 022889001 and 022909471 , respectively (fig. 6). During 2016, the annual loads were 10,479 and $15,243 \mathrm{t}$ at 022889001 and 022909471, respectively. Carbon export in South Florida could be substantially affected by changes in flow patterns caused by changes in rainfall patterns from climate change or by changes in water management.

The total aquatic carbon export was calculated as $42.0 \mathrm{gC} / \mathrm{m}^{2} / \mathrm{yr}$ in 2016 , the only complete year of record for this study. This value is substantially larger (about 15 times) than the overall mean riverine carbon export of dissolved inorganic carbon and total organic carbon of $6.4 \mathrm{gC} / \mathrm{m}^{2} / \mathrm{yr}$ for the eastern United States (Stackpoole and others, 2014). While the Sweetwater Strand study included particulate inorganic carbon in TC calculations, the contribution of particulate inorganic carbon was minimal. The monthly mean aquatic export was only negative in May 2016 and was -0.7 gram of carbon per square meter for that month (fig. 7). With the exception of March, April, and May 2017, when no flow occurred, all other monthly exports were positive, indicating that flow through the area was a source of carbon to downstream systems. The largest monthly aquatic export was 44.1 grams of carbon per square meter for September 2017, which was greater than the annual carbon export per square meter for all of 2016. The September 2017 carbon export was influenced by extensive rainfall from Hurricane Irma, when the flow substantially increased, and the concentrations varied minimally (fig. 4). Carbon export in South Florida is substantially impacted by storm activity and by the environment the water flows through, which itself could be affected by changes in water management. Different ecosystems have different exports of carbon. 

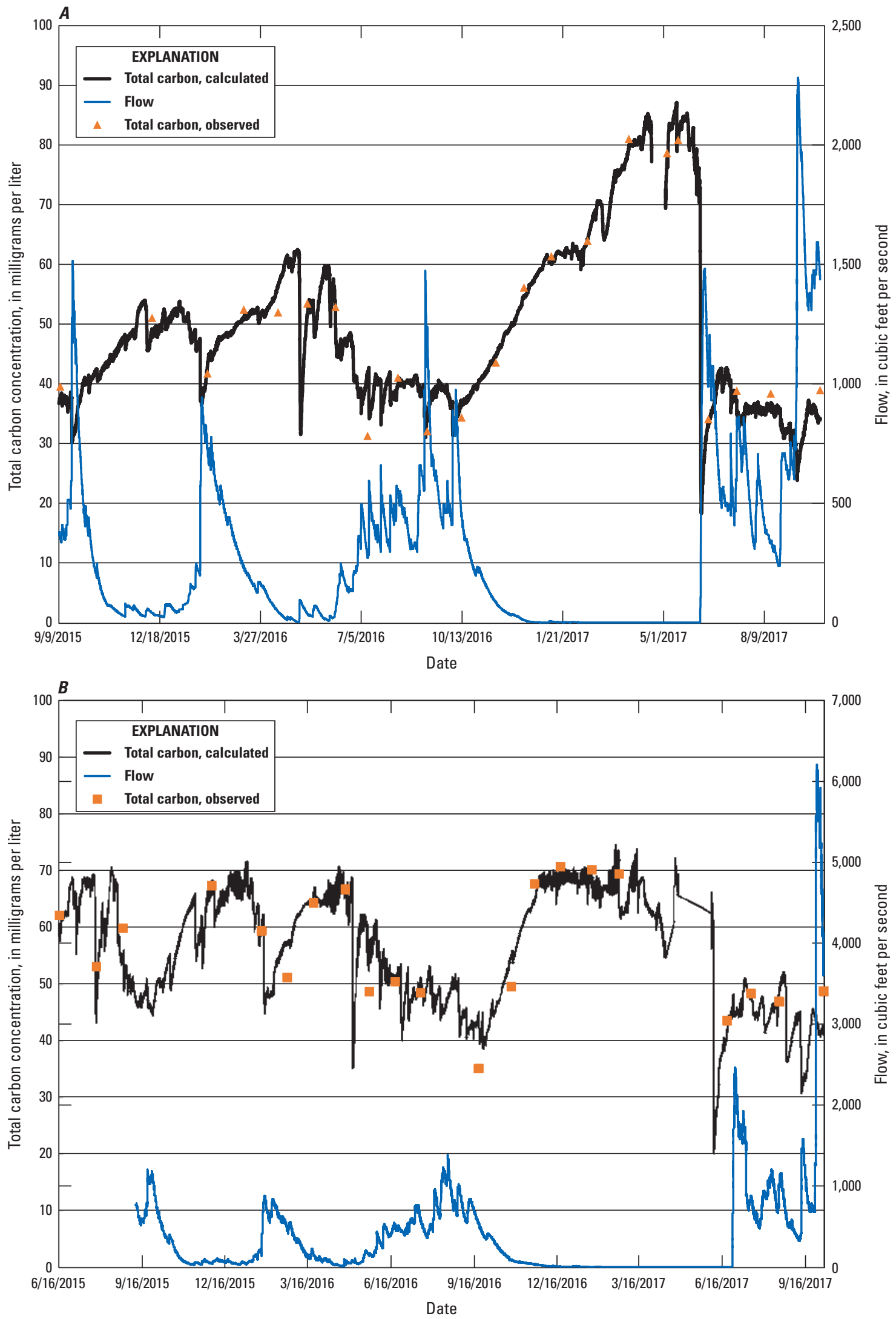

Figure 4. Calculated and observed total carbon concentrations and flow at $A$, U.S. Geological Survey (USGS) station 022889001, and B, USGS station 022909471. 


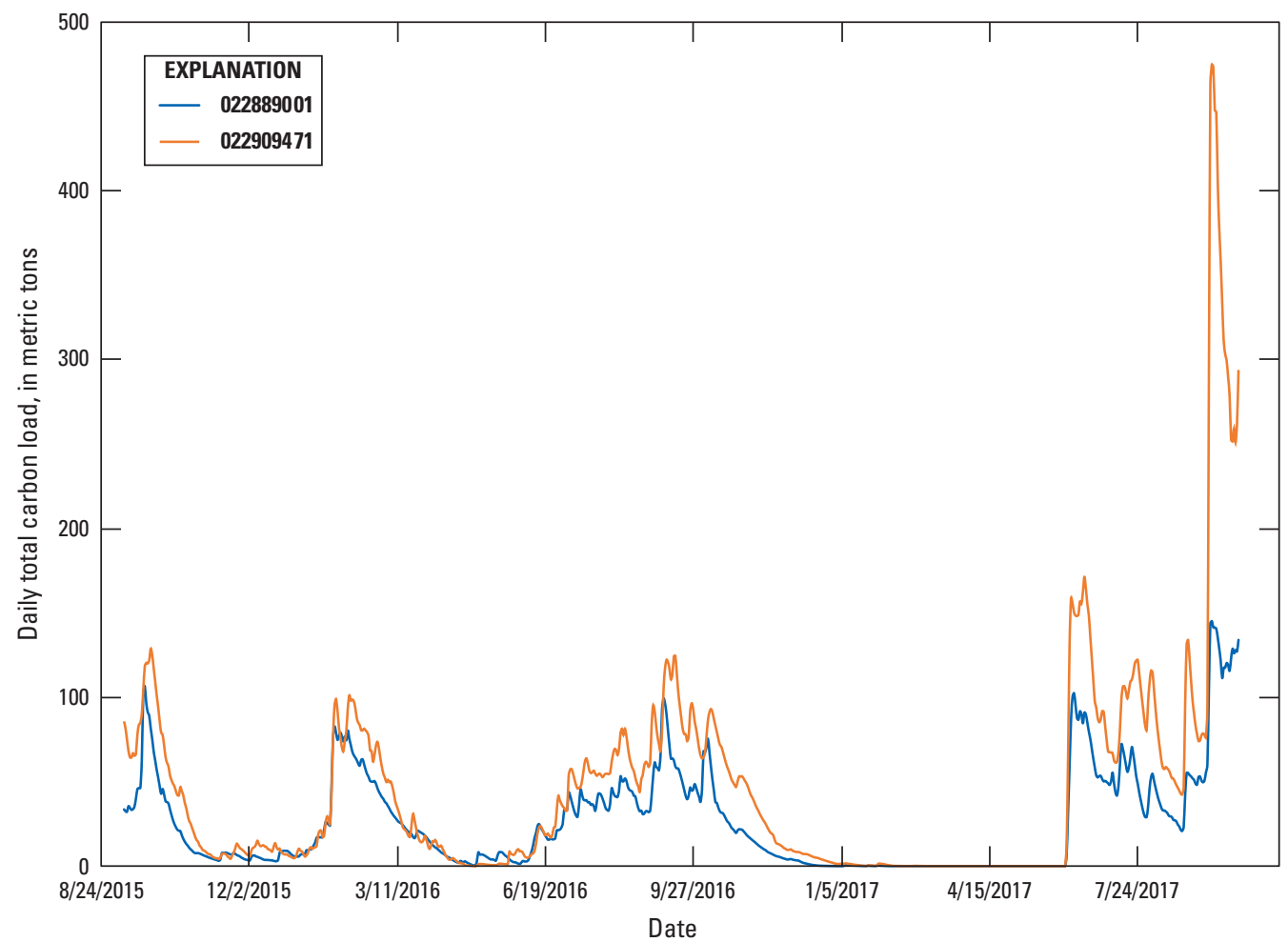

Figure 5. Daily total carbon loads, in metric tons, at U.S. Geological Survey stations 022889001 and 022909471.

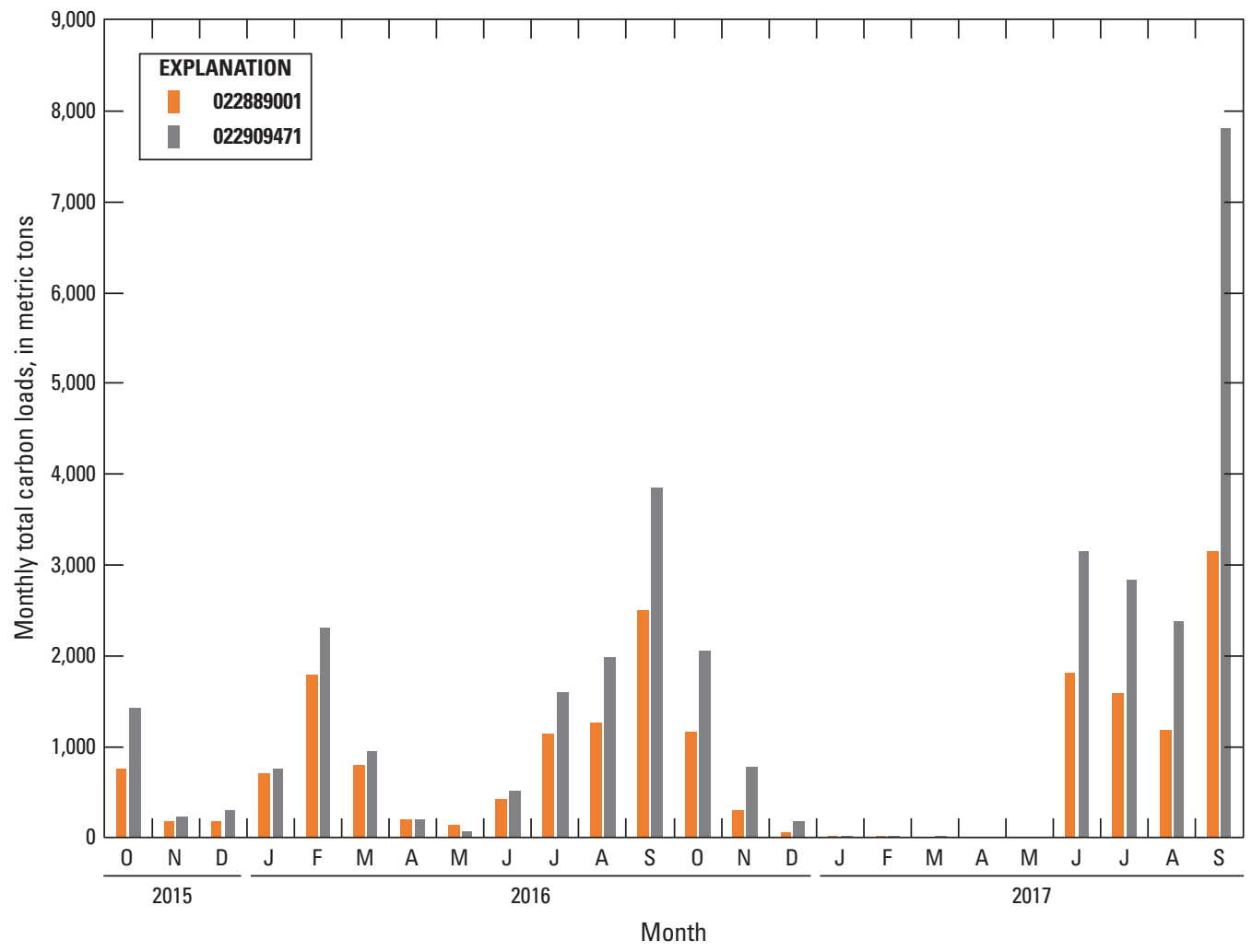

Figure 6. Monthly total carbon loads, in metric tons, at U.S. Geological Survey stations 022889001 and 022909471. 


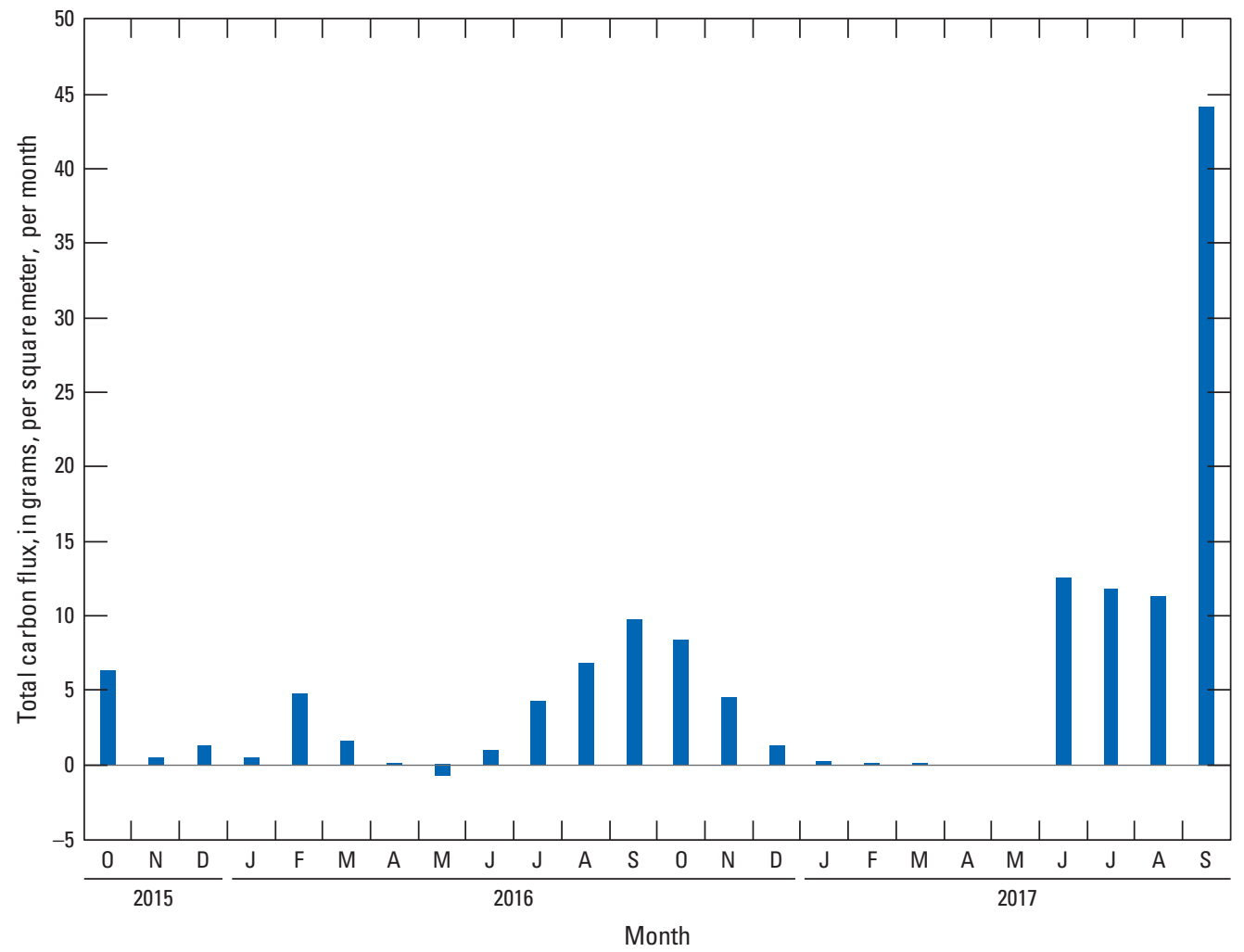

Figure 7. Monthly aquatic export of total carbon, in grams per square meter, for the study area.

\section{Summary}

Understanding carbon transport within flow components is crucial to understanding the global carbon budget. Continuous water-quality and flow data were collected at two stations in Big Cypress National Preserve during 2015-17. Discrete water-quality samples were collected monthly at each of these locations and analyzed for dissolved organic carbon, dissolved inorganic carbon, and particulate inorganic and organic carbon. Regression models were developed to establish site-specific relations between the sum of total carbon (TC) concentrations and continuously measured specific conductance to calculate concentrations of TC. Station 022889001 represents the input into Sweetwater Strand from Tamiami Trail and station 022909471 represents outflow along Loop Road. Calculated concentrations and flow were multiplied to calculate TC loads. The difference between the upstream and downstream load calculations divided by the study area extent represented the aquatic carbon export from the study area. This report documents the regression models and load calculations and will be used as an input to a more comprehensive carbon budget incorporating landscape and atmosphere interactions for Big Cypress National Preserve.
The study area was predominately an exporter of carbon via lateral flow to downstream systems. Calculated carbon concentrations ranged from 18.3 milligrams per liter on June 7, 2017, to 87.1 milligrams per liter on May 13-14, 2017. The 2016 carbon export was calculated as 42.0 grams of carbon per square meter per year, which was substantially larger than the overall mean riverine carbon export for the eastern United States estimated previously. Monthly carbon export within the lateral flow in the study area ranged from -0.7 gram per square meter in May 2016 to 44.1 grams per square meter in September 2017. The September 2017 monthly export of carbon was greater than the entire 2016 export of carbon because of the influence of Hurricane Irma. Carbon export in South Florida could be substantially affected by changes in flow patterns either caused by rainfall changes, storm activity, or anthropogenic water management.

\section{Acknowledgments}

This study was funded by the U.S. Geological Survey (USGS) Greater Everglades Priority Ecosystems Science (GEPES) Program. Nick Aumen (USGS), Barclay Shoemaker (USGS), and Eduardo Patino (USGS) provided helpful conversations during meetings and project presentations. Bryan McCloskey (USGS) aided in determining the study area boundary. 


\section{References Cited}

Abtew, W., and Ciuca, V., 2017, South Florida hydrology and water management, chap. 2 of 2017 South Florida environmental report. Volume 1-The South Florida environment: South Florida Water Management District report, accessed December 10, 2018, at https://apps.sfwmd.gov/sfwmd/SFER/2017_sfer_final/v1/ chapters/v1_ch2.pdf.

Bergamaschi, B.A., Fleck, J.A., Downing, B.D., Boss, E., Pellerin, B.A., Ganju, N.K., Schoellhamer, D.H., Byington, A.A., Heim, W.A., Stephenson, M., and Fujii, R., 2012a, Mercury dynamics in a San Francisco estuary tidal wetland-Assessing dynamics using in situ measurements: Estuaries and Coasts, v. 35, no. 4, p. 1036-1048, accessed October 1, 2017, at https://doi.org/10.1007/s12237012-9501-3.

Bergamaschi, B.A., Krabbenhoft, D.P., Aiken, G.R., Patino, E., Rumbold, D.G., and Orem, W.H., 2012b, Tidally driven export of dissolved organic carbon, total mercury, and methylmercury from a mangrove-dominated estuary: Environmental Science \& Technology, v. 46, no. 3, p. 1371-1378, accessed October 1, 2017, at https://doi.org/ 10.1021/es2029137.

Booth, A.C., 2021, Calculated carbon concentrations, loads, and export in Big Cypress National Preserve, South Florida, 2015-2017: U.S. Geological Survey data release, https://doi.org/10.5066/P9EXZLJT.

Bruhwiler, L., Michalak, A. M., Birdsey, R., Fisher, J.B., Houghton, R.A., Huntzinger, D.N., and Miller, J.B., 2018, Second state of the carbon cycle report [SOCCR2], chapter $1-$ Overview of the global carbon cycle: U.S. Global Change Research Program website, accessed December 15, 2018, at https://doi.org/10.7930/SOCCR2.2018.Ch1.

Cangialosi, J.P., Latto, A.S., and Berg, R., 2017, National hurricane center tropical cyclone report Hurricane Irma (AL112017): National Hurricane Center web page, accessed August 12, 2019, at https://www.nhc.noaa.gov/data/tcr/ AL112017_Irma.pdf.

Clescrei, L.S., Eaton, A.D., Greenburg, A.E., and Franson, M.A.H., 1998, Standard methods for the examination of water and wastewater method $5310 \mathrm{~B}$; total organic carbon (TOC), high temperature combustion method (20th ed.): Washington, D.C., American Public Health Association report, accessed April 28, 2020, at https://edgeanalytical.com/ wp-content/uploads/Inorganic_SM5310.pdf.

Curtis, P.J., and Adams, H.E., 1995, Dissolved organic matter quantity and quality from freshwater and saltwater lakes in east-central Alberta: Biogeochemistry, v. 30, no. 1, p. 59-76, accessed April 24, 2019, at https://doi.org/ 10.1007/BF02181040.
Domanski, M.M., Straub, T.D., and Landers, M.N., 2015, Surrogate analysis and index developer (SAID) tool (ver. 1.0, September 2015): U.S. Geological Survey Open-File Report 2015-1177, 38 p., accessed October 1, 2017, at https://pubs.er.usgs.gov/publication/ofr20151177.

Dreschel, T.W., Hohner, S., Aich, S., and McVoy, C.W., 2017, Peat soils of the Everglades of Florida, USA, in Bülent, T., and Turan, M., eds., Peat: IntechOpen, 16 p., accessed October 1, 2017, at https://www.intechopen.com/books/ peat/peat-soils-of-the-everglades-of-florida-usa.

Everglades Depth Estimation Network [EDEN] and U.S. Geological Survey, 2016, NetCDFto Grid Utility: U.S. Geological Survey South Florida Information Access [SOFIA] online database, accessed December 1, 2016, at https://sofia.usgs.gov/eden/edenapps/netcdftogrid.php.

Monteiro, M.T., Oliveira, S.M., Luizao, F.J., Candido, L.A., Ishida, F.Y., and Tomasella, J., 2014, Dissolved organic carbon concentration and its relationship to electrical conductivity in the waters of a stream in forested Amazonian blackwater catchment: Plant Ecology \& Diversity, v. 7, no. 1-2, p. 205-213, accessed December 1, 2018, at https://doi.org/ 10.1080/17550874.2013.820223.

Pellerin, B.A., Saraceno, J.F., Shanley, J.B., Sebestyen, S.D., Aiken, G.R., Wollheim, G.R., and Bergamaschi, B.A., 2012, Taking the pulse of snowmelt - In situ sensors reveal seasonal, event and diurnal patterns of nitrate and dissolved organic matter variability in an upland forest stream: Biogeochemistry, v. 108, no. 1-3, p. 183-198, accessed January 8, 2019, at https://doi.org/10.1007/s10533011-9589-8.

Perpinan, O., 2016, rasterVis-R package version 0.40: R Foundation for Statistical Computing software release, accessed December 1, 2016, at https://oscarperpinan.github.io/rastervis/.

Rantz, S.E., and others, 1982, Measurement and computation of streamflow-Volume 2. Computation of discharge: U.S. Geological Survey Water Supply Paper 2175, 284 p., accessed January 8, 2019, at https://pubs.er.usgs.gov/ publication/wsp2175.

Rasmussen, P.P., Gray, J.R., Glysson, G.D., and Ziegler, A.C., 2009, Guidelines and procedures for computing time-series suspended-sediment concentrations and loads from in-stream turbidity-sensor and streamflow data: U.S. Geological Survey Techniques and Methods, book 3, chap. C4, 53 p., accessed October 1, 2017, at https://doi.org/10.3133/tm3C4.

Sauer, V.B., and Turnipseed, D.P., 2010, Stage measurement at gaging stations: U.S. Geological Survey Techniques and Methods, book 3, chap. A7, 45 p., accessed October 1, 2017, at https://pubs.usgs.gov/tm/tm3-a7/. 
Spencer, R.G.M., Pellerin, B.A., Bergamaschi, B.A., Downing, B.D., Kraus, T.E.C., Smart, D.R., Dahlgren, R.A., and Hernes, P.J., 2007, Diurnal variability in riverine dissolved organic matter composition determined by in situ optical measurement in the San Joaquin River (California, USA): Hydrological Processes, v. 21, no. 23, p. 3181-3189, accessed October 1, 2018, at https://doi.org/10.1002/ hyp.6887.

Stackpoole, S.M., Butman, D., Clow, D.W., McDonald, C.P., Stets, E.G., and Striegl, R.G., 2012, Baseline carbon sequestration, transport, and emission from inland aquatic ecosystems in the Western United States, chap. 10 of Zhu, Z., and Reed, B.C., eds., Climate projections used for the assessment of the Western United States: U.S. Geological Survey Professional Paper 1797, 18 p., accessed December 1, 2018, at https://pubs.usgs.gov/pp/1797/pdf/ pp1797_Chapter10.pdf.

Stackpoole, S., Butman, D., Clow, D., McDonald, C., Stets, E., and Striegl, R., 2014, Carbon sequestration, transport, and emission from inland aquatic ecosystems in the eastern United States, chap. 5 of Zhu, Z., and Reed, B.C., eds., Baseline and projected future carbon storage and greenhouse gas fluxes in ecosystems of the eastern United States: U.S. Geological Survey Professional Paper 1804, p. 71-84, accessed December 1, 2018, at https://pubs.usgs.gov/pp/ 1804/pdf/pp1804_chapter5.pdf.

Stackpoole, S., Butman, D., Clow, D., Verdin, K., Gaglioti, B., and Striegl, R., 2016, Carbon burial, transport, and emission from inland aquatic ecosystems in Alaska, chap. 8 of Zhu, Z., and McGuire, D., eds., Baseline and projected future carbon storage and greenhousegas fluxes in ecosystems of Alaska: U.S. Geological Survey Professional Paper 1826, p. 159-188, accessed December 1, 2018, at https://pubs.usgs.gov/pp/1826/ pp1826_chapter8.pdf.
Troxler, T.G., Gaiser, E., Barr, J., Fuentes, J.D., Jaffé, R., Childers, D.L., Collado-Vides, L., Rivera-Monroy, V.H., Castañeda-Moya, E., Anderson, W., Chambers, R., Chen, M., Coronado-Molina, C., Davis, S.E., Engel, V., Fitz, C., Fourqurean, J., Frankovich, T., Kominoski, J., Madden, C., Malone, S.L., Oberbauer, S.F., Olivas, P., Richards, J., Saunders, C., Schedlbauer, J., Scinto, L.J., Sklar, F., Smith, T., Smoak, J.M., Starr, G., Twilley, R.R., and Whelan, K., 2013, Integrated carbon budget models for the Everglades terrestrial-coastal-oceanic gradient - Current status and needs for inter-site comparisons: Oceanography (Washington, D.C.), v. 26, no. 3, p. 98-107, accessed October 30, 2020, at https://doi.org/10.5670/oceanog.2013.51.

U.S. Geological Survey, 2019, USGS water data for the Nation: U.S. Geological Survey National Water Information System database, accessed May 7, 2020, at https://doi.org/10.5066/F7P55KJN.

U.S. Geological Survey, [variously dated], National field manual for the collection of water-quality data-Low level mercury: U.S. Geological Survey Techniques of WaterResources Investigations, book 9, chap. A5, section 5.6.4.B, accessed March 16, 2007, at https://water.usgs.gov/owq/ FieldManual/chapter5/pdf/5.6.4.B_v1.0.pdf.

Wagner, R.J., Boulger, R.W., Jr., Oblinger, C.J., and Smith, B.A., 2006, Guidelines and standard procedures for continuous water-quality monitors-Station operation, record computation, and data reporting: U.S. Geological Survey Techniques and Methods, book 1, chap. D3, 51 p., accessed October 1, 2017, at https://pubs.usgs.gov/tm/2006/tm1D3/.

Zimmerman, C.F., Keefe, C.W., and Bashe, J., 1997, Method 440.0 determination of carbon and nitrogen in sediments and particulates of estuarine/coastal waters using elemental analysis: Washington, D.C., U.S. Environmental Protection Agency Report EPA/600/R-15/009, accessed October 1, 2017, at https://cfpub.epa.gov/si/si_public_record report.cfm?Lab=NERL\&dirEntryId=309418. 
Appendixes 1-2. Available at https://doi.org/10.3133/ofr20201136
Appendix 1. Model Archive for Total Carbon Concentration at U.S. Geological Survey Station 022889001: Tamiami Canal 11 Mile Road to Monroe Station, Florida
Appendix 2. Model Archive for Total Carbon Concentration at U.S. Geological Survey Station 022909471: Loop Road Culverts Monroe Station to Florida Trail, Florida


For more information about this publication, contact

Director, Caribbean-Florida Water Science Center (CFWSC)

U.S. Geological Survey

4446 Pet Lane, Suite 108

Lutz, FL 33559

(813) 498-5000

For additional information visit

https://www2.usgs.gov/water/caribbeanflorida/index.html

Publishing support provided by

Lafayette Publishing Service Center 


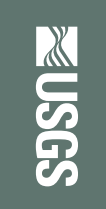

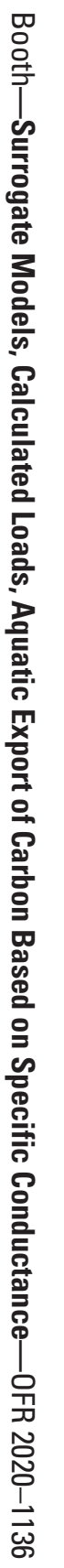

